\title{
SYMBOLIC GREEN : A TIME-HONORED CHARACTERIZING DEVICE IN SPANISH LITERATURE
}

VERNON A. CHAMBERLIN

\section{The University of Kansas}

$\mathrm{T}$ HE national dictionaries of Spain, France, Italy, and Portugal all confirm the fact that the color green has a special and important connotative value-amorous desire-in Latin countries that does not exist in today's English-speaking world, though at one time it was clearly present in English literature. ${ }^{1}$ Because any marked difference in cultural symbols merits investigation, the present study attempts an explanation of symbolic green as a cultural phenomenon by tracing its continuity in Spanish literary tradition. No claim is made to completeness, but instead the focus is upon the more important and more interesting examples which best show variety, evolution, and continuity.

As folklorists, anthropologists, and historians will verify, the origins of symbolic green may be as old as the human race itself and probably arose spontaneously in independent parts of the globe. While many colors readily lend themselves to symbolic notions, green has a special affinity for attracting symbolic meaning because of its links to the basis of life. It is the first and principal color to be observed in the annual renewal of plant life. In ancient Egypt, for example, green was identified with Osiris, god of vegetation and of the River Nile-the river actually taking on a greenish color before its yearly soil-enriching inundation. At this season, the Nile was believed to contain not ordinary water, but the "life substance" of Osiris; and Egyptians consequently painted the god's statues green in deference to his functions and attributes, new life and fertility. ${ }^{2}$

In northern and central Europe where the winters were long, severe, and confin- ing, the advent of spring was especially welcome. A time for merrymaking and frolicking, the season gave greater opportunity and inclination for libidinous expression. Because green was the happy and triumphant color of this pleasant season general$\mathrm{ly}$, and the color of warmth, new life, and fertility specifically, it is understandable that persons motivated by the sweet emotions of love should also respond to nature and imitate her by mimicking her color. Likewise they dressed themselves in green. ${ }^{3}$ Thus green became the favorite garb of any one in love who wished to express and communicate this fact.

In ancient Rome, the fountainhead of Latin culture, green was the color associated with several deities of fertility and love; and perhaps as a consequence of temple prostitution, green became the distinctive color preferred, and usually worn, by courtesans. ${ }^{4}$ This particular symbolism was so well understood and extensively used that green finally came to be the appropriate color of dress for any person "der auf eines Liebesabenteuer ausging."

When literature was able to flourish anew after the fall of Rome and the Dark Ages, the amorous connotations of green passed readily into medieval cultures. Green had a vital part to play in the lore of precious stones and in the fashionable elaboration of courtly love within the chivalric code. ${ }^{6}$ Green-clad characters became much in evidence in the literature of western Europe. The nearperfect Christian knight Sir Gawain found it necessary to make a practical accommodation to the Green Knight and the latter's green-girdled wife. ${ }^{7}$ Boccaccio dressed his lovesick women in green, ${ }^{8}$ while Chau- 
cer thought the color more appropriate for his "unconstant women" who were seeking new adventures. ${ }^{9} \mathrm{~A}$ French folksong states, "Il te fauldra de vert vestir,/C'est la livrée aux amoureulx"10 and characters did just that in such works as L'Amant rendu cordelier a l'observance d'amours ${ }^{11}$ and Guillaume de Machaut's Le Livre du voirdit. $^{12}$ Some medieval fictional gallants even revealed their innermost psychic urges by dreaming of green-clad women, ${ }^{13}$ and in Germany, Meister Altswert allegorized Frau Liebe as green-garbed. ${ }^{14}$

During the Renaissance, with its increased zest for living life to the fullest, the symbolic use of erotic green appears to have intensified. Jean Lemaire de Belges expressed his feelings in Les Epitres de l'amant vert; ${ }^{15}$ but Henri IV of France, perhaps, best personifies the spirit of the time, becoming immortalized as "le Vert Galant." ${ }^{16}$ French soldiers sang of greenclad girls, ${ }^{17}$ and Englishmen first published the well-known and hauntingly beautiful ballad of the lady with the Greensleeves (1580). ${ }^{18}$ And in the 1590 's, Spenser allegorized Lechery as green-clad in his Faerie Queene (I, iv, 25.1). Juliet pined for Romeo because she was suffering from the "green sickness" (III, v, 156), and Shakespeare has the Spaniard Don Adriano de Armado say that "green is indeed the color of lovers" (Love's Labor Lost, I, ii, 83). But, after the seventeenth century, the broader symbolic connotations of green lessened in the English-speaking world, although, of course, scattered instances have survived. These do not evoke, however, the immediate recognition of green as a sexually oriented symbol so typical in Hispanic cultures.

Hope, as an additional connotation of green, undoubtedly arose in connection with the phenomenon of pleasant seasonal change, the renewal of life, and man's desire for immortality. It still survives as such in many modes of expression, including Christian liturgical symbolism, especially the seasons of Trinity and Epiphany. Hope early became intertwined with the libidinous connotations of green, and thus the color most often signified new or unattained, but hoped-for, love.$^{19}$ Logically, the reverse connotations of green when it denotes jealously and envy, as in expressions such as "green-eyed monster" or "green with envy," may be but negative aspects of the same phenomenon, having their basic origins in the frustration of hoped-for libidinous expression. Be that as it may, the present focus concerns itself with amorous desire, the only one of the four principal connotations of green which is almost entirely non-operative in the Anglo-Saxon world of today.

In Spain a romance viejo of the Cid cycle describes one of the defenders of Zamora as "vestido de verde, porque estaba enamorado." ${ }^{20}$ A more delicate touch is observed in the ballad En Covaledo de Duero where a family forces a sensitive young girl to marry a rich old man and murders the younger suitor of her choice. "Cuando en la sala la buscaron / no encontraron ni cuerpo ni alma, / sólo que un pájaro verde / cantando al son del agua." ${ }^{21}$ If one accepts the idea that eyes are the windows whence the soul looks out, then it is indeed appropriate for the fatally enamoured Melibea of the Celestina to have "ojos verdes, rasgados." 2 The bawdy old protagonist of La loçana andaluça (1528) advises the color green for a young man who would go courting. ${ }^{23}$ Amadís de Gaula, certainly Spain's most popular caballero andante, was signifcantly known as "El Caballero de la Verde Espada",24 and a knight-errant might find, as Palmerín de Inglaterra did, among those ladies in distress one lying on a green cushion surrounded by four green candles burning perpetually. ${ }^{25}$ Although Cervantes did not choose to develop the characterization of his "Caballero del Verde Gabán" in Don Quijote along these lines, ${ }^{26}$ such famous authors as Quevedo, Salas Bar- 
badillo, Castillo Solórzano, Mateo Alemán, and Baltasar Gracián all clearly appreciated the amorous symbolism of green. ${ }^{27}$

Consequently, one surmises that the Spanish theatergoers of 1617 were undoubtedly well prepared by time and tradition to understand and thoroughly enjoy the chromatic symbolism in Tirso de Mo lina's famous Don Gil de las calzas verdes. ${ }^{28}$ Because this play depends so thematically upon special connotative uses of green, it merits a more detailed discussion than the preceding examples. The Golden Age's penchant for dressing women in men's clothing and having the plot complication depend upon several confused identities is made all the more delightful by having a number of the characters openly wear libidinous green. In the play the young feminine protagonist, who has been seduced and abandoned, follows her lover to Madrid disguising herself as a man and appears in the opening scene "con calzas $y$ vestido todo verde" for the purpose (as is later explained) of thus reminding her gallant what he has lost (p. 1634). Playing the role of her own unfaithful suitor, she pays court to the rich woman for whom she has been abandoned. She succeeds so well that her rival soon unwittingly describes her as having "una cara como un oro, / de almíbar unas palabras, / y unas calzas todas verdes, / que cielos son y no calzas" (p. 1617). The play's gracioso is even more frank and earthy, describing the rich woman as "la damaza de la huerta / por las verdes calzas muerta" (p. 1627). Consequently, Don Gil (really the abandoned feminine protagonist in disguise) soon comes to enjoy the reputation "en obras ... [así como] en nombre es verde" (p. 1636). The play reaches its climax amid additional puns on the word "verde," along with the added complication and delightful confusion caused by other characters also deciding to wear "calzas verdes." Finally a typical siglo de oro denouement sorts out all the green-clad characters, and the un- faithful lover does at last agree to fulfill his original promise of marriage.

It was not always necessary to dress a character in green for a theatrical audience to catch and enjoy the chromatic symbolism intended by the playwright. In the extremely popular little sainetes of Ramón de la Cruz, for example, such a subtitle as Los viejos verdes ${ }^{29}$ sufficed to alert playgoers to what they could expect.

Even as late as 1886 , the audience was expected to respond to the symbolism of green without actually seeing it represented on the stage. In Ricardo de la Vega's Pepa la frescachona, names serve as one of the prime indicators of true character. Pura and Casta Verdecilla are two women ("viuda joven" and "soltera joven," respectively) who strive to project the idea that they are veritable incarnations of their given names. The audience, however, soon discovers that they are probably neither "casta" nor "pura" and are treated to the good fun of seeing the ladies inadvertently reveal themselves as libidinously motivated personifications of their surname -Verdecilla. ${ }^{30}$

Nineteenth-century prose writers were even more inclined toward creative innovations in the use of symbolic green. Like so many other Romantics, Gustavo Adolfo Bécquer was able to find his inspiration in medieval folk belief and successfully combine it with the prevailing esthetic of unrestrained expression, passion, and suicide. Bécquer utilized the widespread European folk belief that young people must be wary of strangers wearing or in any way showing the color green. Such strangers were often thought to be disguised demons of sexuality, who desired to lure the innocent into the forests in order to effect their perdition. $^{31}$ In Los ojos verdes (1861), Bécquer creates a young nobleman who sees-or more probably, projecting and displacing his own feelings, imagines that he sees-a beautiful young girl in a forbidden wooded pool. She is characterized repeat- 
edly by her "ojos verdes" 32 and then reveals that she is "un espíritu puro, no . . . una mujer como las que existen en la tierra" (p. 97). She promises to love the young man in a "lecho de esmeraldas," giving him "una felicidad sin nombre, esa felicidad que has soñado en tus horas de delirio" (p. 97). The nobleman, consequently, loses his life pursuing her lips beneath the surface of the green-colored pool.

As early as the Renaissance, European authors spoke of the youthful years of life figuratively as the "green years," and usually with amorous overtones. Góngora is possibly one of the most skilled with this usage. Note the ballad "La más bella niña," in which a young widow "en tan tierna edad" laments "¿quién no llorará / aunque tenga el pecho / como un pedernal, / y no dará voces / viendo marchitar / los verdes años / de mi mocedad?" ${ }^{3}$

Conversely, a person who demonstrates the amorous inclinations of youth in a manner or degree inappropriate to his advanced age was, and still is, called a "viejo verde" $^{34}$ (already noted in connection with Ramón de la Cruz). Occasionally such a personage might be treated sentimentally as in Leopoldo Alas's short story El viejo verde where the protagonist inadvertently finds himself bathed in light streaming through a green-colored window. ${ }^{35}$

However the "viejo verde" was usually an antipathetic character ${ }^{36}$ and nineteenthcentury realistic novelists often showed green in the very skin coloring of their characters as though the internal amorous drive of the personaje was so intense that it betrayed itself externally. Although this technique served to reveal to the reader a deep-seated inner reality, it was, of course, when viewed objectively, completely nonrealistic and only symbolic. Thus an esthetic problem of the nineteenth-century novelist was sometimes one of finding a method of harmonizing these two conflicting realities.

One approach was that of frank and open caricature. This is the method used by Pedro Antonio de Alarcón in his El sombrero de tres picos (1874). The entire plot and interpersonal conflicts of the novel result from the fact that the very ugly and grotesque Corregidor has amorous intentions symbolized by a "rostro moreno verdoso" and a cloak "muy festoneada de ramillos verdes ... [indicando] la lujuria ... [de este] medio libertino," "tan aficionado a las faldas." 38 Thus fully apprised of the true character of the Corregidor when he is first presented, readers the world over (in many languages) ${ }^{39}$ have delighted in seeing this villainous "viejo verde" thwarted at every turn and then outwitted and paid in kind by his wife.

Pérez Galdós also sought ways to employ the non-realistic symbol of connotative green for the depiction of deep-seated emotional realities. In some of his early novels Galdós simply caricatures and exaggerates much in the manner of Alarcón. For example, the Marqués de Tellería in $L a$ familia de León Roch (1878) is such a "viejo verde" 40 that even the temples of his forehead are "surcadas de venas verdes" (p. 856). Similarly, in El doctor Centeno (1883) when the student Alejandro Miquis ruins his health, partly by consorting with ladies of easy virtue, his neck degenerates into "un haz de cuerdas revestidas de verdosa cera" and his eyes exude a "fulgor de verde" (p. 1431). In the same novel, Father Pedro Polo suffers to such an extent from an illicit and impossible love affair that his face turns "verde, como oxidado bronce" (p. 1334).

As early as 1876 , Galdós was also using green in dream settings, realms which, of course, removed him completely from any danger of artistic conflict with external reality. In Doña Perfecta, for example, the reader is aware that Rosario Polentinos perceives subconsciously the true nature of the degenerate and lascivious political boss "Caballuco." He appears in Rosario's 
dream as "más semejante a un dragón que a un hombre ... con ojos verdes, con dos grandes linternas de convexos cristales. Aquel fulgor y la imponente figura del animal le infundían miedo ... [porque] el dragón agitaba sus brazos . . . y revolvía los globos verdes, tan semejantes a los fanales de una farmacia, de un lado para otro. Su mirar cegaba" (p. 479).

Eight years later (1884), at the height of his best realistic period, Galdós chose to omit deforming caricature, like that of the dragon, but still retained his earlier use of erotic green. Little Isabelita de Bringas ( $L a$ de Bringas) sees in a dream the politician Manuel del Pez dressed in "calzones verdes" (p. 1637). Of course the worldly wise and consummately clever $\mathrm{Pez}$, the man who is soon to seduce and ruin her mother, would never actually wear such a telltale costume; but Isabelita's subconscious evaluation of his character and motivations later proves to be completely accurate. ${ }^{41}$

As these examples suggest, Galdós clearly allows the reader to enter the psyche of his characters to learn how one personaje really impresses another-how one character may intuitively perceive the "true colors" of another. But it is not until Angel Guerra (1890-97), that Galdós portrays directly the feelings of a libidinously frustrated character himself. Putting his protagonist into an unconscious, dreamlike state, Galdós attempts to depict graphically Guerra's excruciating sufferings by introducing wild animals who gnaw and rend his flesh. Prominent among these are "dragones con ojos de esmeralda."

Unfortunately, in the hands of less conscientious and less skilled authors, the naturalistic novel (in Spain as well as in other countries) in the late nineteenth and early twentieth century sometimes degenerated into open pornography. This type of novel became so widespread and the green-clad characters in such works as Luis Antón del Olmet's Cruz verde, 8 so scandalous, that Carlos Fortuny was motivated to write an entire volume of criticism entitled La ola verde. ${ }^{43}$

The advent of the impressionistic novel, with its more suggestive, delicate, and sensitive techniques of characterization, brought a refreshing change. In Don Juan (1922),Azorín presents a series of women who have succumbed, it is hinted, to the protagonist's charms. ${ }^{44}$ Azorín achieves this subtle suggestion by insinuating, in the presentation and portraiture of each woman, that she is responsive and amorous. In the case of Angela, he makes repeated reference to her emerald ring. "¿En qué se piensa Angela ... [cuando] clava la vista en la esmeralda; [cuando] hay, entonces en su cara un arrebol de epicureísmo satisfecho[?]." Azorín never gives an exact answer but notes in the room "un ligero ambiente de enardecimiento y de voluptuosidad" and then ends his entire portraiture of Angela on the word "verde." 45

The "esperpentic" novel of Valle-Inclán entitled Tirano Banderas, novela de tierra caliente (1926) presents probably the most strikingly unique personaje in all of Spanish literature to be characterized by green. The traditional erotic values of green are here complicated and distorted by the admixture of completely extraneous but combinative elements.

First the author explains that the green oozing continually from the corners of the protagonist's mouth is caused by the chewing of coca leaves. ${ }^{46}$ Indeed the cruel dictator does seem to be completely selfnarcotized against all feelings of humanity and compassion. Although Valle-Inclán soon ceases to call attention to the cause of the green on the dictator's face, he continues to insist on the color. Then he establishes in other contexts, primarily in the chapter " $\mathrm{La}$ recámara verde," very definite erotic connotations for green. "La recámara verde" is the inner part of a brothel where green is the predominant 
color (pp. 717-29). Green is likewise associated with the compulsively homosexual Spanish ambassador (pp. 802-04). Thus it is logical to adduce (in a novel with impressionistic aspects by a writer so wellknown for his erotica as Valle-Inclán) that the green oozing from the corners of the dictator's mouth may also have a deeper level of significance-an overflowing of deep-seated, brutal, and pernicious sensuality. ${ }^{47}$

In any case, the bizarre and repulsive image of Santos Banderas is heightened by the fact that he has a nervous twitch or tic (with an accompanying "clac, clac" sound) which turns his mouth into a veritable "mueca verde." The entire concluding part of the novel (libro séptimo) entitled "La mueca verde" emphasizes the grimace in its climactic moments until it tends to become disassociated from, but stands for, the totality of the character Santos Banderas. The "mueca verde" in this way gives a distorted image of the dictator and, as one critic has said, "este color contribuye a crear el tono esperpéntico de la novela." ${ }^{48}$

Even more complex is García Lorca's antithetical use of green in the Romance sonámbulo. Green (as already noted) has traditionally been the color of vegetation (life) but even in ancient times it was also the color of corpses (death and decomposition). Osiris, the green-colored god of vegetation and life was ironically the god of death as well, because the mythical ritual of vegetation deities follows the pattern of death and rebirth. Although some of the examples already discussed in this study embody, at least latently, the ambivalent and antithetical life-death use of green (most notably Bécquer's Los ojos verdes, Galdós's Alejandro Miquis in $E l$ doctor Centeno, and Valle-Inclán's Tirano Banderas), it is possibly best illustrated in Lorca's famous poem. A gypsy girl waits on a balcony full of amorous desire for her lover. "Verde, que te quiero verde" verbalizes the longing of the girl, surrounded by "verde viento, verdes ramas." 49 She seems to dream of being so fulfilled that she may have "verde carne, pelo verde" (p. 20). However, when her lover arrives, he is mortally wounded. Climbing to the "verde baranda" (pp. 22-23), he unexpectedly finds the girl dead: "sobre el rostro del aljibe/ se mecía la gitana./ Verde carne, verde pelo" (p. 23). Lorca ends his poem by highlighting the fate of the girl (and her lover) who became "green" in a tragic and ironical sense; and he contrasts the antitheses of death and life, by returning to the poem's initial (and incremental) amorous refrain of "verde, que te quiero verde."

The very nature of poetry and the novel as art forms permit refinements in the use of symbols which would go unnoticed by a theater audience. It is probably for this reason that the twentieth-century Spanish theatre still continues with verve the Renaissance tradition of actually dressing appropriate performers in green. For example, when the curtain rises on the first act of Alfonso Paso's contemporary play Cosas de papá y mamá (1960), the spectator is treated to the sight of a gentleman not only dressed entirely in green but standing in a room in which everything elserugs, wallpaper, sofa, and even the telephone-is also green. ${ }^{50}$ The audience has already seen this gentleman in the prologue, listless and full of complaints in a doctor's office. There he chanced to meet "mamá," a widow who soon attracts and completely rejuvenates him. When "mamá" comes calling, she nearly faints upon seeing "papá" openly and happily expressing his new-found emotions by means of his green suit and his newly decorated green living room. ${ }^{51}$ Love soon transforms the widow also, but the rest of the play revolves around their cleverly overcoming the objections of their teenage children. As a climax, "papá" appears at his wedding, not only dressed in green as promised, but also, as an added flourish, carrying a green hat and green gloves (p. 308). The couple's 
physician, from the beginning clearly the author's razonador, has the culminating speeches of the play, testifying to the curative powers of love and adding that after the marriage his services were never needed again (pp. 308, 311).

Other illustrations might be added, ${ }^{52}$ including examples from Latin American literature. ${ }^{53}$ However, the works already discussed demonstrate clearly that creative Spanish authors of all the major genres have used the color green as an important facet of characterization from at least Renaissance times to the present. Famous authors of nearly every major literary movement have been able to adapt it to the prevailing literary esthetic. Even in the socalled realistic novel of the nineteenthcentury this nonrealistic symbol was successfully employed in a number of ways. It served not only as an external marking to indicate inner emotions but it was also a part of the symbolism used in dreams to allow the reader to view and comprehend the active functioning of the subconscious.

While continually maintaining the ancient custom of dressing libidinously motivated persons in green clothing, Spanish authors have used such additional devices as external skin coloring, colored lights, emerald rings, green-colored furniture, mythological animals, dreams, names, and puns to suggest amorous overtones. They have indeed insisted that libidinous desire is a vital, dynamic aspect of the human make-up and have perennially and frankly reflected many facets of it in female as well as in male characters, and in the aged as well as in the young. The contemporary view as expressed by the sympathetic physician in Cosas de papá y mamá is that love can be a completely wholesome, positive, and vital regenerative force.

\section{A} LTHOUGH THE CONNOTATIONS of hope, envy, and jealousy which green expresses so prominently in today's Englishspeaking world are not unknown in Span- ish literature, ${ }^{54}$ green has been used and still is used primarily as a symbol of love and libidinous desire. It is also germane to note here that a Spaniard never speaks of an off-color or risqué story, joke, or song but rather uses the expressions "cuento verde," "chiste verde," and "canción verde." Similar values for green were vibrantly alive and widespread in English literature, song, and popular speech until the advent of Puritanism..5 Today, however, the amorous symbolic meaning of green has so completely lost its force that the average educated American does not respond at all to the symbolism of green either when seeing it used so prominently on the stage in such a play as Paso's Cosas de papá y mamá or in discussing it later. ${ }^{56}$ Americans seem to have been oblivious to the implications of Shirley MacLaine's costume, entirely green, on the cover page of Life magazine (June 21, 1963) where she appeared in the character of Irma (la douce). They likewise missed the humor resulting from the puns concerning her costume in the very popular Hollywood version of that French play. ${ }^{57}$ Students and colleagues, however, born and educated in Spain almost unanimously recognize that deliberate symbolism is employed in both Cosas de papá y mamá and Irma la douce and give interpretations in accord with the symbolic values advanced here..$^{58}$ Spanish literature, perhaps because it experienced neither the repressive influence of English Puritanism nor later Victorian prudishness, has maintained in its pristine form, an ancient, nature-inspired symbol which still serves as important and very effective means of understanding between the author and his public.

\section{NOTES}

'See "Verde," Diccionario de la lengua española, Real Academia Española (Madrid, 1956), p. 1328; Giuseppe Rigutini, Vocabolario italiano della lingua parlata (Firenze, 1854), p. 1268; Laudelino Freire, Grande e novíssimo dicionario da lingua portuguesa (Rio de Janeiro, 1957), v, 5167; Diçtionaril Limbii Romîne Moderne (Bucareşti, 1958), p. 925; "Verd," Pompeu 
Fabra, Diccionari general de la lengua catalana (Barcelona, 1954), p. 1717; "Vert galant," Emile Littré, Dictionnaire de la langue française (Paris, 1956), III, 2003.

2Donald A. Mackenzie, "Colour symbolism," Folklore, xxxiI (1922), 155-61.

${ }^{3}$ Cf. Walther Gloth, Das Spiel von den sieben Farben (Königsberg, 1902), p. 60, and Paulus Cassel, Der grüne Papegei. Eine Symbolik des Grünes ... . (Berlin, 1888), p. 3. Lovers might also become "green-gowned" by rolling in the grass, especially during May Day festivities. Cf. Robert Herrick, "Corrina's Going A-Maying," The Anthology of English Literature (New York, 1962), p. 823-25.

4Pierre Dufour, Geschichte der Prostitution, trans. Adolf Stille (Berlin, n.d., 3rd ed.), r, 39. See also C. L. Rochholz, Deutscher Glaube und Brauch (Berlin, 1867), I, 283.

5Dufour, Geschichte, p. 39.

'See, among others, the references listed by Gloth, Das Spiel von den sieben Farben, pp. 58-62.

"Sir Gawain and the Green Knight," The Norton Anthology of English Literature (New York, 1962), pp. 183-238. I am indebted to a number of colleagues for their interest and help in locating examples used in this study: Gerard C. Flynn, Herman Iventosch, Seymour Menton, Myra Olstead, Dorothy Thelander, Bruce Wardropper, and others.

${ }^{8}$ Decameron (Firenze, 1952), p. 278.

9"Against Women Unconstant," Complete Works, ed. F. N. Robinson (Boston, 1933), p. 636.

${ }^{10}$ Cited by Gloth, Das Spiel, p. 61.

${ }^{11}$ Chansons françaises $d u X V e$ siècle, ed. G. Paris (Société des anciens textes français, 1875), No. 40 , p. 50 , cited in Jean Lemaire de Belges, Les Epitres de l'amant vert, ed. Jean Frappier (Lille, 1948), p. xxi.

${ }^{12}$ Guillaume de Machaut, Le Livre $d u$ VoirDit (Paris, 1875), pp. 82, 213, 214, 240, 299, 309, 313, 347, 351. Cited by J. Huizinga, Herbst des Mittlealters, trans. T. Jolles Mönckeberg (München, 1924), p. 164.

${ }^{13}$ Huizinga, Herbst, p. 164.

14"Diz heizet der Kittel" and "Der tugenden Schatz," Meister Altswert (Stuttgart, 1850), pp. $29,44-45,84,86$.

${ }^{15}$ See note 11 above.

${ }^{16}$ See Grand Larousse Encyclopédique (Paris, 1962), v, 847.

${ }^{17}$ Chansons (1538), cited by Gloth, p. 62.

18Robert Nares, A Glossary or Collection of Words, Phrases, Names and Discussions to Customs ... (Stralsund, 1825), p. 337.

${ }^{19 H u i z i n g a, ~ H e r b s t ~ d e s ~ M i t t l e a l t e r s, ~ p . ~ 164 ; ~}$ Gloth, Das Spiel, pp. 58-59. Cf. Don Cameron, "Symbolic Color in English Renaissance Literature," Philological Quarterly, xv (1936), 85-86. For the entire spectrum of chromatic symbolism regarding love, see Herbert A. Kenyon, "Color
Symbolism in Early Spanish Ballads," Romanic Review, vI (1915), 327-340; and S. Griswold Morley, "Color Symbolism in Tirso de Molina," Romanic Review, viII (1917), 77-80.

20"Romance catorce," Flor nueva de romances viejos, ed. R. Menéndez Pidal (Madrid, 1943), p. 193.

${ }^{21}$ For a Sephardic variant, see Menéndez Pidal, Los romances de América y otros estudios (Madrid, 1958), p. 153.

22(Madrid, 1871), pp. 275, 276.

${ }^{23}$ Ed. Julio Cejador y Frauca (Madrid, 1913), p. 55 .

${ }_{24}$ Biblioteca de autores españoles, $\mathrm{xL}, 215 \mathrm{~b}$, 216b, 314b-315a.

${ }^{25} \mathrm{Nueva}$ biblioteca de autores españoles, $\mathrm{xI}$, $335 \mathrm{~b}$

${ }^{26}$ Ed. Rodríguez Marín (Madrid, 1912), Clásicos castellanos, XIII, 280-342. Because of the complication of additional colors, this character (and others in Cervantes' works) merits a separate study. Cf. Thebussem, "Lo verde Len Cervantes]," La España moderna, LxIII (1894), 4360; and S. Griswold Morley, "Color Symbolism in Tirso de Molina," Romanic Review, vII (1917), 77-80.

${ }^{27}$ Excellently demonstrated in Baltasar Gracián, El criticón, ed. M. Romera-Navarro (Philadelphia, 1938), I, 212, n. 152 with quotations and complete bibliographical entry. See also II, p. 40, n. 160. For Quevedo, see Obras completas, ed. Luis Astrana Marín (Madrid, 1952), II, 391.

28Obras dramáticas completas, ed. Blanca de los Ríos (Madrid, 1946), 1, 1603. All subsequent references are to this edition.

${ }^{29}$ Usually listed as El viejo a la moda (1772). See Emilio Cotarelo, Don Ramón de la Cruz y sus obras (Madrid, 1899), p. 428; and (for text) Sainetes de Don Ramón de la Cruz (Madrid, 1928), II, 290-297.

${ }^{30}$ Nineteenth Century Spanish Plays, ed. Lewis E. Brett (New York, 1935). See especially p. 789 , n. 1; and p. 804, n. 53.

${ }^{31}$ Cassel, Der grüne Papagei, pp. 43-46, 61.

32Obras (Madrid, 1924), r,pp. 94, 96, 98. All subsequent references are to this edition.

${ }^{33}$ Poesías, ed. Eduardo Juliá Martínez (Madrid, 1929), pp. 22-24.

${ }^{34} V$ iridis was used metaphorically and symbolically already in Latin times and the wellknown expression "viejo verde" derives from senex viridis (an expression used by several Latin authors) and became wide-spread in Spain during the Renaissance. See, among others, Diccionario de autoridades (Madrid, 1964), II, 461; and Martín Alonso, Enciclopedia del idioma (Madrid, 1958), III, 4148.

${ }^{35}$ Cuentos de Clarín, ed. Laura de los Ríos de García Lorca (Boston, 1954), pp. 27, 33-34.

${ }^{36}$ Sometimes also in Spanish painting. Cf. Enciclopedia universal ilustrada, LxviIr, 995.

37Ed. Edmund de Chasca (Boston, 1952), pp. 23-24. See also p. 1, lines 23-24. 
38Ibid., p. 25.

39In The Three-Cornered Hat (New York, 1928), Martin Armstrong not only translates "verde" literally but also has a colored illustration clearly depicting the Corregidor as decidedly green-complexioned.

${ }^{40}$ Obras completas, ed. F. C. Sainz de Robles, $4^{a}$ edición (Madrid, 1960), rv, 783. All subsequent references are to this edition.

41For additional details, see my "Galdós' Chromatic Symbolism Key in 'Lo prohibido'," Hispanic Review, xxxII (1964), 110-17.

42Obras, 2a edición (Madrid, 1950), v, 1485. 43(Barcelona, 1931). See especially pp. 229-36. ${ }^{44}$ (Madrid, 1927), p. 181, et passim.

${ }^{45}$ Pp. 132-33; Angela's sister, Sor Natividad also significantly has "ojos verdes" (p. 37, cf. 14l-42) and Virginia wears "un jubón verde" (p. 144).

460bras completas (Madrid, 1952), pp. 676, 689,690 . All subsequent references are to this edition.

${ }_{47}^{4}$ Tirano Banderas' final act is to murder his own daughter (whom he keeps imprisoned [pp. 713-14]) so that his enemies may not possess her sexually (p. 830). The following statement is one of Valle-Inclán's most explicit regarding the deep-seatedness of the dictator's cruelty: "la mueca verde remegía los venenos de una befa aun soturna y larvada en los repliegues del ánimo" (p. 810).

${ }^{48}$ Carmen Iglesias, "El esperpento en la obra de Valle-Inclán," Cuadernos americanos, cV (1959), 231.

${ }^{49}$ Obras completas, ed. Guillermo de Torre (Buenos Aires, 1938), Iv, 20-23. All subsequent references are to this edition. The refrain of "Verde, que te quiero verde," probably also expresses the desires of the girl's gypsy lover.

${ }^{50}$ Teatro español 1959-1960, ed. F. C. Sainz de Robles (Madrid, 1961), p. 258. All subsequent references are to this edition.

51(P. 258.) "Mamá" had previously expressed her feelings inadvertently in a similar vein, by means of the following statement: "el color verde me entusiasma. Por mi gusto, todo lo tendría verde en casa. Hasta los inuebles" (p. 254).

${ }^{52}$ Juan Valera, "Marquita y Antonio," Obras completas (Madrid, 1907), Xmi, 17-18; Pepita Jiménez, (Madrid, 1963), p. 38; "El pájaro verde," Obras (Madrid, 1887), II, 9-44; ValleInclán, "La cabeza del dragón," Opera (Madrid, 1924), x, 14, et passim; Fernán Caballero, La gaviota (Madrid, 1964), p. 101; and Jorge Guillén, "Verdor es amor," Cántico (Mexico, 1945), p. 182.

${ }^{53}$ For example, Rafael Arévalo Martínez, "El hombre verde," El hombre que parecía un caballo $y$ otros cuentos (Guatemala, 1951), 85-97; MarioVargas Llosa, "La casa verde," Diálogos, I (1964), 7-10; and in Brazilian literature, Gre gório de Matos, "A uma Dama vestida de verde," Obras, ed. Academia Brasileira (Rio de Janeiro, 1930), v, 293. (Cf. also Ricardo Palma's title, "Tradiciones en salsa verde," typescript ms. on deposit Duke Univ. Library).

${ }^{54}$ For hope, see Agustín Moreto, "El desdén con el desdén," Comedias escogidas (Madrid, 1922), Biblioteca de autores españoles, IXL, 9; Tirso, "Don Gil," pp. 1638, 1648; Herbert A. Kenyon, "Color Symbolism in Early Spanish Ballads," Romanic Review, vi (1915), 329-30; S. Griswold Morley, "Color Symbolism in Tirso de Molina," Romanic Review, virI (1917), 7780. For envy, see Pérez Galdós, "Gloria," Obras, rv, 681; for jealousy, see Galdós, "Angel Guerra," Obras, v, 1300.

55See especially Farmer and Henly, Dictionary of Slang and its Analogues (London, 1893), Irr, 205.09; and Eric Partridge, Shakespeare's Bawdy (London, 1955), p. 123.

56 See note 58.

${ }^{57}$ Irma wears green because she is a prostitute.

58I have not only observed a number of educated friends during the performance of both these works but, more importantly, have sampled reactions by questionnaires and interviews. 